\title{
Exploring the Personal Philosophies of Volunteerism among Professors at a Malaysian Research University
}

\author{
Samuel Olutokunbo Adekalu *, Steven Eric Krauss, Suandi \\ Turiman, and Ismi Arif Ismail \\ Universiti Putra Malaysia, Malaysia
}

\begin{abstract}
Many argue that the changing nature of research universities globally is making the academic profession demanding. Academics are expected to do more, produce more, and 'justify their existence' at their respective universities often in the form of outcomes-based performance measures that are historically foreign to the academic profession. At the same time, they may have to engage in volunteerism outside the academy. Despite much existing research on volunteerism within the context of higher education, a few studies have been conducted on volunteerism among senior academics in non-Western countries, in an attempt to understand how academics balance these pluralistic roles and responsibilities, and the personal philosophy behind their ongoing engagement in volunteerism. To address this gap, this study explored the personal volunteerism philosophies of university professors from a leading research university in Malaysia. Using a purposeful sampling approach, the authors conducted in-depth, semistructured qualitative interviews with seven professors from different academic departments who have regular engagement in volunteering activities beyond their internal academic obligations. Interviews were recorded and transcribed verbatim. From the analysis, three factors were found to contribute to the formulation of the personal philosophies about volunteerism. These were: (a) individual orientation and exposure; (b) religious beliefs; and (c) work related identities. Volunteerism was found to foster recognition for academics in their related field of expertise. The study concludes with suggestions for enhancing the volunteerism experiences of academics and implications for future research.
\end{abstract}

\footnotetext{
* Corresponding Author: S. O. Adekulu; email: adekaluolutokunbo@gmail.com http://orcid.org/0000-0001-8847-6465 (Received 07 February 2017; Revised 27 April 2017; Accepted 20 July 2017) (C) OUSL
} 
Keywords: Community Engagement, Personal Philosophy, University Professor, Volunteerism.

\section{Introduction}

It is very difficult to volunteer, if I detach myself from my academic work, because academic work is my life, I don't have free time... For example, I go home with three [students' theses], and read up to 3:00 am in the morning, when would I have time to do volunteering work outside of my academic work? (Informant 1, Professor).

It is widely known that academics' varied responsibilities are taxing and time consuming. Consequently, many academics complain that they have little time for volunteering activities (Bailyn, 2003; Neumann, Terosky \& Schell, 2006; Kogan \& Teichler, 2007; Terosky, O'Meara \& Campbell, 2014). Yet, the contribution of academics to volunteerism cannot be underestimated. Professorship is a highly prominent position in the academic profession and volunteer work is an extension of an academic career often critical for faculty members to gain real-world work experience and to boost the reputation of their respective institutions. Professors are acknowledged leaders in their subject fields and most influential in the academic world (Tight, 2002; Ismail, 2005; Neumann et al., 2006; Ismail, Silong, Asimiran \& Hassan, 2011; Safiah, Mohd-Taib, Norliah \& Mahadi, 2012). Becoming a professor is not the final destination of an academic career, but a means to continue with one's work and to be confident of one's ability (Ismail, 2005; Terosky, 2005). At present, in formal organizations like universities, corporate organizations, ministries and government agencies where professors are mostly employed, it is often assumed that voluntary engagement in knowledge sharing and service to community by professors is undervalued due to numerous commitments in the form of teaching, research, scholarship and service (Boyle \& Sawyer 2010; Terosky et al. 2014).

The terms "volunteerism" and "volunteer" are defined differently depending on the cultural, religious, and geographical diversity to which volunteerism is applied. Volunteerism involves rendering of service by choice or freewill for the benefit of the wider community by an individual, group, or institution without necessarily expecting monetary gain in full knowledge and 
appreciation of being a volunteer (Huiting, 2011). Aside from this definitional perspective, there could be other individual reasons that reveal a personal philosophy of why people engage in volunteering activities. Some people tend to volunteer to promote a cause they feel strongly about, while others choose volunteerism as a way to 93gain skills to develop individual careers or to build communal reputation (Musick \& Wilson, 2003).

A comprehensive review of the literature on volunteerism conducted as a backdrop to this study revealed that few studies attempt to address personal philosophies around volunteerism. According to Merriam (1982) personal philosophies are critical for informing one's practice. The word "philosophy" has many definitions considering the various arguments among scholars. However, in this study, we assumed "philosophy" is a defining part of an academic's career experience based on intension and reasons that informs the decisions and actions that academics make for their meaningful engagement in volunteering work. Past studies have revealed that having a personal philosophy is related to a greater sense of empowerment, happiness and achievement, which sometimes shape one's beliefs and behavior, choices and decisions, and dictate motivations (Askhiem, 2003; Paul, 2007).

In the last three decades, in spite of a growing literature on volunteerism, very little is known about academics' engagement in volunteerism specifically (Eisenberg \& Fabes, 1998; O’Meara, 2003). Most academics studying for or holding $\mathrm{PhD}$ degrees, particularly university professors at various stages in their careers, have to function as volunteers or pseudovolunteers within their community of practice and respective institutions (Ismail, 2005). However, the general perception of volunteerism is that it is often undertaken out of one's own free will in the quest to help others. In this study, volunteerism is defined as an act of making choices to share and do things, to support community and society in ways that go beyond one's basic obligations (Michael, 2008). Unveiling the elements around personal philosophies of volunteerism among senior academics is important because of the relationship between volunteerism, community development and academic career trajectories. One of the primary aims of community development is to facilitate cooperation and support in the community through volunteerism (Midgley \& Livermore, 1998). Among the selected criteria in promoting academics' career prospects is regular engagement in 
social work, which can be sustained through volunteerism (Ismail, 2005; Safiah et al., 2012; Terosky et al., 2014).

Although previous studies have identified a number of factors relating to the reasons why people participate in volunteer work, few have attempted to give voice to the personal philosophies behind volunteerism, particularly among academic staff. Several studies related to volunteerism in universities and colleges have focused on student engagement (Bradford, 2005; Holdsworth, 2010, Turiman et al., 2011; Darwen \& Rannard, 2011; Nazilah, Rozmi \& Fauziah, 2014), while a few have addressed academics' engagement in volunteerism. Some related studies have shown associations between people engagement in volunteerism and personal beliefs (Greenslade \& While, 2002; Law \& Shek, 2009; Jasmin, Turiman, Hamzat \& Ismail, 2015), and family-of-origin upbringing/orientation (Rosenhan 1973; Clary \& Miller 1986; Hart \& Fegley, 1995; Lee, 1998; Fletcher, Elder \& Mekos, 2000). Lee (1998) in her study of 566 student volunteers in Hong Kong, found that volunteer role identity was related to parental volunteering, perceived expectations and to their intention to volunteer during their college careers. In response, the current study focuses on academics, specifically professors, and the personal philosophy that drives their participation in volunteerism. Academics' contribution to community development encompasses the different ways that they support community beyond their academic obligations of research, teaching and consultancy. The engagement of academics in volunteerism often plays a dual role of advancing the general mission of the university as well as providing a mechanism for improving the wellbeing of the people in the community (Hussin \& Mohd Arshad, 2012). It is also a means of gaining meaningful work experience, as well as developing skills that are necessary for professional development. Above all, there is limited research on the underlying philosophies behind why academics volunteer. The question of how one defines his or her personal volunteerism philosophy and what form that personal philosophy takes has yet to be addressed.

\section{The Current Study}

Personal philosophies can be simple, developing, or well-developed. Philosophy in the context of the current study represents an individual statement about volunteerism based on personal experience and academic background, in the course of one's career development. The core responsibilities of academics in Malaysian universities revolve around a 
three-in-one function of teaching, research and service provision. This unique blend of tasks distinguishes them from pure educators, service providers or researchers of other corporate and public organizations (Maimunah \& Roziah 2008). Specifically, senior academics in Malaysian public research universities are expected to produce more scholarly work and to integrate their research findings directly into their teaching. This added burden is one that academics from teaching universities in the country do not share. Moreover, academics at research universities are expected to share research findings with the community as volunteers outside the academy. Hence, this study aims to contribute to the volunteerism and higher education literatures by unveiling the personal philosophies of university professors' engagement in volunteerism, outside of their core responsibilities of teaching, research, and consultancy. The study sets out to answer the core research question, "how do university professors describe their volunteerism philosophy?"

\section{Methodology}

Based on the exploratory nature of the research purpose, face-to-face, indepth, semi-structured qualitative interviews were used to collect the study data. A purposive sampling method was employed and informants were selected using a criteria-based approach. The criteria for inclusion in the current study were three: (a) informants had to be senior academics in the rank of full professor; (b) they had to come from different academic fields of study; and (c) they had at least twenty years of career work with expertise in volunteerism, as it was assumed that those who had more regular engagement in volunteering activities would be able to provide more indepth data. The study data were obtained at the public university with the highest number of PhD-level academic staff in Malaysia. This university was approved as a research university (RU) by the Malaysia Government with a reputation for excellence in teaching and research. We initially contacted fifteen professors from different academic departments within the university and seven responded to the invitation to partake in the research. Interviews were held at the study participants' offices in the university.

Among the seven participants, five were males and two were females. Six of the professors were Muslim and one was Buddhist. The age of the informants

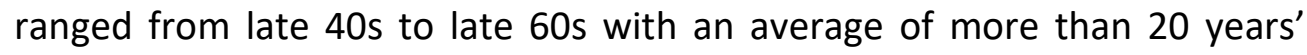
experience in academia. The participants came from different academic backgrounds including Educational Studies, Engineering, Human Ecology, 
Agriculture, Pure Sciences, Social Sciences and Business. The informants all had Doctoral degrees from overseas institutions, namely the United States, United Kingdom, Belgium, and Australia. All of the informants were Malaysian nationals. Within the sample, one was a Professor Emeritus, while the remaining six were full Professors.

Each interview lasted approximately forty minutes. Interviews were taperecorded and transcribed verbatim. Data analysis was done manually. The lead author carried out the interviews while the other team members engaged in peer debriefing and reading over the data and results for threats to trustworthiness and validity (Creswell, 2007). The professors' identities were coded to ensure their anonymity and confidentiality. The below table shows the details of the professors who participated in the research.

Table 1: Profiles of Informants

\begin{tabular}{|c|c|c|c|}
\hline INFORMANTS & ACADEMIC STATUS & AREA OF EXPERTISE & GENDER \\
\hline Informant 1 & Professor & Youth Development & Male \\
\hline Informant 2 & Professor Emeritus & Extension Education & Male \\
\hline Informant 3 & Professor & Community Development & Male \\
\hline Informant 4 & Professor & Accounting & Female \\
\hline Informant 5 & Professor & Soil Science & Male \\
\hline Informant 6 & Professor & $\begin{array}{c}\text { Human Resource } \\
\text { Development }\end{array}$ & Female \\
\hline Informant 7 & Professor & Electrical Engineering & Male \\
\hline
\end{tabular}

\section{Results}

The results illuminated informants' personal philosophies about volunteerism, which encompassed three main elements: (a) individual orientation and exposure, (b) religious beliefs and (c) work related identities (See Figure 1). 


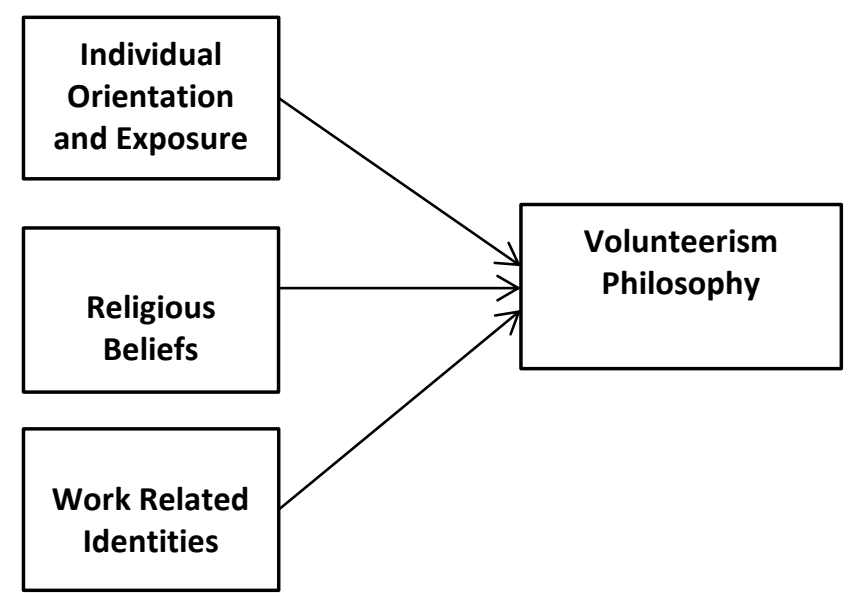

Figure 1: Main elements emerged in the volunteerism philosophy

\section{Individual Orientation and Exposure}

In today's world, people live in societies where individual or group's action and interest are dominant. This dimension refers to how people define themselves and their relationship with others. Life decisions such as career choices and intention for volunteerism are normally made by individual themselves based on orientation. Gerpott, Domsch, and Keller (1988) define individual orientation in the context of work careers as preferences concerning types of work-related values, performance standards, and forms of recognition. Exposure includes attitudes, beliefs, and behaviors toward a variety of issues and topics (Hall, 2005). As revealed by the participants, individual orientation and early life exposure to volunteering activities helped the professors formulate a personal philosophy about volunteerism in the course of their academic career development. For example, informant 1 , a professor in the field of youth development, defined his personal volunteerism philosophy as, "Fulfilling the right of others, without demanding your own in return". Part of what helped form this volunteerism philosophy was his exposure to scouting during his early school days. He elaborated:

Volunteerism is part of the field I am in now. I remember during my early school days, there were many organizations in the school so I preferred to join the scouting group. In scouting they always prepare you to become volunteers. Anytime I go to my community, I volunteer to develop those 


\begin{abstract}
young scouts in my village that were not privileged to continue their studies due to economic constraints. I trained them in entrepreneurship programmes and community work. So, my exposure to scouting contributed to my interest in volunteering.
\end{abstract}

Informant 7, a professor with 30 years' experience in the field of electrical engineering, defined his volunteerism philosophy as, "Happy humanity as a whole." The informant believed people should be happy helping others in need, but due to a lack of proper education and experience, some people do not acquire an orientation that allows them to help others. For him, exposure to scouting built his foundation for engaging in volunteering work. He stated:

I remember at age seven. I was part of the boy scouts in my primary school days and during the course of my scouting life I was exposed to do volunteering work from "house to house"... So, I think the training from childhood influenced me to do volunteer work.

Informant 2 was a Professor Emeritus in field of Extension Education, and was also a former Vice Chancellor of a public university. He believes strongly in the adage that, "the hand that gives is more honourable than the hand that receives." He described his engagement in volunteering work as a way to ensure community wellbeing. His standing volunteerism philosophy is, "Serve others and give them the opportunity to reveal themselves." To him, human beings are like flowers that must be given water to grow. He cited one of his personal experiences in volunteerism as follows:

I was young in the university when I started volunteer work. Though I would say that my up-bringing have been a source of inspiration for me to get involved in volunteering, I learnt this from my father whom in his time often took me to the farm at age five to work to raise money to train other people to school. One of my successful volunteerism projects was called "Let the villages decide". In this project, I received a \$5000 grant for community leadership from the Malaysian government, which I gave to the community. Later when I visited the community, they asked me what we should do with the money. I replied saying I don't know, and that they should decide what to do with the money. The next time I visited them they said they wanted to have a workshop, which I built 
for them. This little project was developed in five villages, one has a village library. When I left, the villagers cried!

Informant 4, a professor of accounting also mentioned the role of exposure and experience on developing the desire to volunteer when she stated:

My volunteerism philosophy is basically "For Mutual benefit", based on the exposure I had in my field of expertise, one is expected to be up-to-date on different methods in solving problems -- I believe through engagement in volunteer work, I gain something from you and you also gain something from me. We gain to learn new things, exposure to new environments, meeting people and establishing networking, in terms of expertise.

\section{Religious Beliefs}

Religious beliefs are a common theme found in much of the literature on volunteerism and are often associated with reasons associated with engagement in volunteer work. The decision to engage in volunteer work is often determined by individual beliefs and intentions (Jasmin et al., 2015). Despite the religious differences of the study participants, the analysis revealed that religious beliefs were an important element of the participants' personal philosophy. For example, Informant 1 , despite his commitment to academic work, believed his engagement in volunteering was influenced by his faith. He stated:

I do engage in volunteering work because it is "part and parcel of me" to make life better for others because that is what my religion teaches. For example, I believe that if I see people who are in need of help, and I have the chance to help but I fail to help them, that means I am not human myself.

Informants 3 and 7 also emphasized the importance of religious beliefs on their philosophy of volunteerism.

I believe if I make you happy, God will make me happy... I don't want to be the only person to reach the sky; I want everybody to get to the top. I feel joyful to [share with people], motivating them as "agents of change". (Informant 3) 
I do volunteer work because it is "ordained by God" to share knowledge and wealth with people and the community. (Informant 7)

Although he didn't elaborate on the meaning of "reach the sky," informant 3 was clear that the happiness he derived from participating in volunteering activities was a major part of what his religion teaches. Efforts to meet people's needs and lead them on the 'right path' was part of what kept informants 3 and 7 moving forward in their academic careers.

Informant 6, who specializes in human resource development, reflected on her own volunteerism philosophy through what she called, "Citizenship behavior". To her, citizenship behaviour means involvement for community connectedness, which entails going beyond one's basic career-related tasks in order to connect and collaborate with others in the community. She further explained how her faith connects her to community-based volunteer work:

My involvement volunteer work is more of religious activities, through women's engagement. I do join religious associations, where I am invited to give religious talks in communities, compare with my colleagues who often participate in all kinds of volunteering activities.

\section{Work Related Identities}

Work related identities refer to the different ways in which individuals define themselves within the context of work (Fugate, Kinicki, \& Ashforth, 2004). In this study, networking evidence of university professors' engagement in volunteerism through professional and social organizations helped to shape their academic identities. Informants 7, 5, and 4 believed that volunteering in professional and social organizations in term of knowledge sharing is a part of their effort to support people in their related field of expertise:

I do volunteering work for professional activities locally and internationally, this I do outside of my academic work, I'm a registered professional engineer in Malaysia. Also, I'm a fellow of the Institute of Engineers Malaysia as well as, the Institute of Electrical and Electronics Engineers (New York, United States). In these professional organizations, I served in various capacities, as a secretary and member of 
committees, where I offer professional advice, to support the upcoming engineers. (Informant 7)

I am actively involved in voluntary organizations, but many of my involvements are related to my work. I am currently a committee Member of the Professional Council (Majlis Professor Negara). Also, I am one time president of various professional bodies like Agricultural Institute of Malaysia (AIM), International Society for Southeast Asian Agricultural Sciences (ISSAAS), Malaysian Society of Soil Science, Malaysian Professional Centre, UPM Academic Staff Association, among others. (Informant 5)

Basically as for me, I'm very much involved in professional work; I'm a qualified accountant and a member of the professional bodies in this country. So I get involved in their projects, for example. I'm involved in setting the development of accounting standards for this country. I also serve as an examiner for their professional examinations. (Informant 4)

This was evident with the other professors as well, some who spoke directly about how their engagement in volunteering activities -- in line with their respective academic disciplines -- helped them get recognition and build an academic identity in their area of expertise. In this regard, Informants 1,3 and 4 said:

As professors, our areas of expertise varies, most of the time opportunities are open in that we are often called by organizations and government to give talks, develop modules/curriculum, or to be part of policy formulation. For this purpose, in the field of youth development where I specialized, I have been privileged to volunteer serving as an advisor and resource person to various organizations and government in term of policy formation. In recognition, I do receive a lot of awards from my contributions to youth development, within and outside Malaysia. (Informant 1)

I have delivered more than 700 motivational talks on how to develop the society in various workshops, seminars, 
conferences, and through newspapers, radio and television, which has earned me a lot of recognition and awards, both nationally and internationally. (Informant 3)

I render volunteer works with other universities, cooperate sectors, professional bodies and general public in term of extension services. For example, the ministries may need expertise from academics to volunteer, when they are doing the accreditations of a new programme... Sometime when am free, I do volunteer as an evaluator, and assessor for some of the new programmes, especially those programs offered at the private colleges and universities, and my engagement in some of these activities has made me gain commendation in my filed. (Informant 4)

\section{Discussion}

Regarding the main study objective, the findings help to understand how our participants describe or define their philosophy of volunteerism. In line with related past research, the findings revealed that their engagement in volunteer work supported their career development (Tight, 2002; Ismail, 2005; Newmann et al., 2006; Ismail et al., 2011; Safiah et al., 2012; Terosky et al., 2014). The findings also resonate with studies showing that religious belief is an important factor influencing people's engagement in volunteerism, and the role of religious belief in promoting altruism (Hunter \& Linn, 1980; Wuthnow, 1999; Greeley, 1997; Mattis, Jagers, Hatcher, Lawhon, Murphy \& Murray, 2000; Lam, 2002).

People's engagement in volunteer work cannot be completely separated from their family orientation, academic background, and individual life exposure, particularly early-life experiences. Although the informants did not mention the influence of family upbringing, early exposure to volunteerism and academic background were discussed at length. According to Eisenberg and Fabes (1998) and Fletcher et al. (2000) family experiences are important inputs for the development of altruistic behavior. Rehberg (2005) and Gran (2006) described the likeliness of international experience impacting on individual motivation for volunteerism. Gaskin (2004) further posited that individual exposure to early participation in community service can reduce barriers to volunteerism, while experiential learning through direct 
experiences has been found to be a strong factor in attitudinal changes (Cummins \& Lau, 2003).

The results demonstrate how volunteering helps to sustain professional identities and, in turn, career development. Career development has been defined as an individual's resolution to meet career-improvement demands as they present themselves in comparison to their contemporaries that face the same demands (Gonzalez, 2008). The academic profession is generally considered a supportive and helpful profession, in which individual experiences and enthusiasm to impact others are recognized as motivations that draw individuals to the profession (Fischman, Schutte, Solomon \& WuLam, 2001). Nevertheless, the enthusiasm to serve others must be sustained over time. Sustaining an academic career requires not only a determined commitment of time and energy into appropriate activities, but also demands access to appropriate resources and institutional assistance that facilitates career feasibility (Ismail, 2005; Crepeau, Thibodaux \& Parham, 1999; Terosky et al., 2014). This determined commitment of time is a function of career development.

\section{Conclusions, Recommendations and Directions for future Research}

This study explored the personal philosophies of volunteerism among a group of non-Western university professors. The philosophies of the academics comprised of three factors that contributed to their on-going engagement in volunteer work. Serving the community allowed them to engage in knowledge sharing and, in turn, opened doors for further opportunities in their related fields. Engaging in volunteer work thus enhanced the professors' qualifications and recognition both within and outside the academic community (Ismail, 2005).

Although the findings are limited to one public university in Malaysia, similar educational institutions may find the results of this study useful for providing consideration toward developing avenues to promote greater involvement of academicians in volunteer work beyond their regular engagement in teaching, research and consultancy. Individual orientation and exposure to volunteerism were found to be significant factors for the academics' involvement in volunteerism. Although the participants referred to volunteer exposure in their youth, past research indicates that exposure in adulthood 
can also be an effective socializing agent for involvement in volunteerism (Hill \& Kevin, 2013; Johnson et al., 1998). Therefore, policies and programs within universities that foster volunteer interest might encourage young academics to volunteer subsequently contributing to their career development and overall job satisfaction.

The study findings can also begin to address certain misconceptions about faculty members' engagement in volunteer work. It is often assumed that most university professors do not engage in volunteer work due to a growing number of work-related responsibilities (Terosky et al., 2014). However, the study revealed that our professors' religious beliefs, individual orientation and exposure, and work related identities contributed greatly to the meaning they derive from volunteer work. Nonetheless, the professors' engagement in volunteer work is most often directed toward their respective areas of expertise. Consequently, their engagement is often mistaken for 'normal' academic work (Boyle \& Sawyer, 2010). Furthermore, time constraints help to explain the professors' limitations of engagement in volunteer work.

This study is not without limitations, in particular, the size of the sample and overall scope limit our ability to generalize beyond the sample and setting studied. On this note, we suggest that future research consider increased sample sizes and broadened methods and settings to explore the dimensions and challenges to engagement in volunteerism among academicians, particularly in other non-Western settings.

\section{Acknowledgment}

This work was supported by the Petroleum Technology Development Fund (PTDF) Nigeria.

\section{References}

Askheim, O. P. (2003). Empowerment as guidance for professional social work: An act of balancing on a slack rope. European Journal of Social Work, 6 (3), 229-240.

Bailyn, L. (2003). Academic Careers and Gender Equity: Lessons Learned from MIT. Gender, Work and Organization, 10 (2), 137-153. 
Boyle, M. \& Sawyer, J. (2010). Defining volunteering for community campaigns: An exploration of race, self-perceptions, and campaign practices. Journal of Community Practice, no. (18), 40-57.

Clary, E. G. \& Miller, J. (1986). Socialization and situational influences on sustained altruism. Child Development, no. (57), 1358-1369.

Crepeau, E. B., Thibodaux, L. \& Parham D. (1999). Academic juggling act: Beginning and sustaining an academic career. American Journal of Occupational Therapy, no. (53), 25-30.

Creswell, J. C. (2007). Qualitative inquiry \& research design: Choosing among five approaches. 2nd ed. Thousand Oaks, CA: Sage.

Cummins, R. A. \& Lau, A. L. D. (2003). Community integration or community exposure, a review to people with an intellectual disability. Journal of Applied Research in Intellectual Disabilities, no. (16), 145-157.

Darwen, J. \& Rannard, A. G. (2011). Student volunteering in England: a critical moment. Education Training, no. (53), 177-190.

Eisenberg, N. \& Fabes, R. A. (1998). Prosocial Development. In Damon, W. \& Eisenberg, N. Handbook of Child Psychology eds. 5th ed. Social, emotional and personality development, no. (3), 701-778. New York: Wiley and Sons.

Fugate, M. \& Kinicki, A. J. \& Ashforth B. E., (2004). Employability: A psychosocial construct, its dimensions and applications. Journal of Vocational Behavior, 65 (1), 14-38.

Fischman, W., Schutte D., Solomon B. \& Wu Lam G. (2001). The development of an enduring commitment to service work. New Directions for Child and Adolescent Development, no. (93), 33-44.

Fletcher, A. C., Elder G. H. \& Mekos, D. (2000). Parental influences on adolescent involvement in community activities. Journal of Research on Adolescence, no. (10), 29-48.

Gaskin, K. (2004). Young people, volunteering and civic service: A review of literature. London: Institute for Volunteering Research.

Gerpott, T. J., Domsch, M. \& Keller, R.T., (1988). Career Orientations in Different Countries and Companies: An Empirical Investigation of West German, British and US Industrial R\&D Professionals. Journal of Management Studies, 25 (5), 439-462

Gonzalez, M. A. (2008). Career maturity: A priority for secondary education. Electronic Journal of Research in Educational Psychology 6 (3), 749-772.

Gran, B. (2006). Public-private obstacles to voluntary service and citizenship. In Williamson, H., Hoskins, B. \& Boetzelen, P. Charting the 
landscape of European youth voluntary activities, eds. 121-133. Strasburg, France: Council of Europe.

Greenslade, J. H. \& White, K. M., (2002). Beliefs underlying above average participation in volunteerism. Australian Journal on Volunteering, no. (7), 29-35.

Hall, A. (2005). Audience personality and the selection of media and media genres. Media Psychology, no. 7: 377-398.

Hart, D. \& Fegley, S. (1995). Altruism and caring in adolescence: Relation to self-understanding and social development. Child Development, no. 66: 1347-1359.

Hill, J. P. \& Kevin, R. D. (2013). Religion, Volunteering, and Educational Setting: The Effect of Youth Schooling Type on Civic Engagement. Journal for the Scientific Study of Religion, 52 (1), 179-197.

Holdsworth, C. (2010). Why Volunteer? Understanding Motives for Student Volunteering. British Journal of Educational Studies 58 (4), 421-437.

Huiting, W. (2011). Social impact of volunteerism. Points of light institute.

Retrieved from

http://www.pointsoflight.org/sites/default/files/sitecontent/files/soci al impact of volunteerism pdf.pdf

Hunter, K. I. \& Linn, M. W. (1980). Psychosocial differences between elderly volunteers and non-volunteers. International Journal of Aging and Human Development 12 (3), 205-213.

Hussin, Z. \& Mohd Arshad, M. R. (2012). Altruism as Motivational Factors toward Volunteerism among Youth in Petaling Jaya Selangor. International Proceedings of Economics Development \& Research, 225229.

Ismail, I. A. (2005). Moving on in academia: exploring the career experiences of professors at a UK university. PhD dissertation., University of Warwick.

Ismail, I. A., Silong, D. A., Asimiran, S. \& Hassan. Z. (2011). Development of educational leadership in Research University through community of practices among professors. Procedia Social and Behavioral Sciences, no. (15), 828-832.

Jasmin A. S., Turiman S., Hamzat, S. R. \& Ismail, I. A. (2015). Why Youths Choose to Become Volunteers: From the Perspective of Belief. Athens Journal of Social Sciences 2 (1), 52-64.

Johnson, M. K., Beebe, T., Mortimer, J. T. \& Snyder, M. (1998). Volunteerism in adolescence: A process perspective. Journal of Research on Adolescence 8 (3), 309-332. 
Kogan, M. \& Teichler, U. (2007). Key Challenges to the Academic Profession. UNESCO Forum for Higher Education, Research and Knowledge: Germany: International Centre for Higher Education Research (INCHERKassel),

Lam, P. Y. (2002). As the flocks gather: How religion affects voluntary association participation. Journal for the Scientific Study of Religion 41 (3), 405-422.

Law, B. M. F. \& Shek, D. T. L. (2009). Beliefs about volunteerism, volunteering intention, volunteering behavior, and purpose in life among Chinese adolescents in Hong Kong. The Scientific World Journal: TSW Child Health \& Human Development, no. (9), 855-856.

Lee, L. (1998). Change of self-concept in the first year of college life: The effect of gender and community involvement. Unpublished PhD dissertation, University of Hong Kong.

Maimunah, I. \& Roziah, M. R. (2008). Leadership in an Academic Career: Uncovering the Experience of Women Professors. International Studies in Educational Administration, 36 (3), 87-103.

Mark, S. \& Allen, M. O. (2008). Volunteerism: Social Issues Perspectives and Social Policy Implications. Social Issues and Policy Review, 2 (1), 1-36.

Mattis, J. S., Jagers, R. J., Hatcher, C. A., Lawhon, G. D., Murphy, E. J. \& Murray, Y. F. (2000). Religiosity, volunteerism, and community involvement among African American men: an exploratory analysis. Journal of Community Psychology 28 (4), 391-406.

Merriam, S. B. (1982). Some thoughts on the relationship between theory and practice. In S.B. Merriam, (Ed) Linking philosophy to practice, New Directions for Continuing Education, no. (15) 87-91. San Francisco: Jossey-Bass.

Michael, E. S. (2008). Social work with volunteers. Lyceum Books Inc.

Midgley, J. \& Livermore, M. (1998). Social capital and local economic development: Implications for community social work practice. Journal of Community Practice 5 (12), 29-40.

Musick, M. A. \& Wilson, J. (2003). Volunteering and depression: the role of psychological and social resources in different age groups. Journal of Social Science and Medicine 56 (2), 259-269.

Nazilah, A., Rozmi, I. \& Fauziah I. (2014). The Role of Egoistic Motives for Malaysian College Students' Involvement in Volunteering Activities. Asian Social Science; 10 (19), 173-179.

Neumann, A., Terosky, A. L. \& Schell J. (2006). Agents of learning: Strategies for assuming agency, for learning, in tenured faculty careers. In 
Bracken, S., Allen J. \& Dean, D., eds. The balancing act: Gendered perspectives in faculty roles and work lives, 91-120. Sterling, VA: Stylus. O'Meara, K. (2003). Reframing incentives and rewards for community service-learning and academic outreach. Journal of Higher Education Outreach and Engagement 8 (2), 201-219.

Paul, F. E. M. (2007). Your Philosophy of Social Work: Developing a Personal and Professional Definition to Guide Thought and Practice. Journal of Social Work Values and Ethics 4 (1), 1-11.

Rehberg, W. (2005). Altruistic individualists: Motivations for international volunteering among young adults in Switzerland. Voluntas 16 (2), 109122.

Rosenhan, D. L. (1973). The natural socialization of altruistic autonomy. In J. Maccaulay and L. Berkowitz, eds. Altruism and helping behavior, 98120. New York: Academic Press.

Safiah, S., Mohd Taib, D., Norliah K. \& Mahadi, A. (2012). Academic Career in the Malaysian Higher Education: Becoming a Professor. Journal of Human Capital Development 5 (2), 127-140.

Scheier, I. (1999). A philosophy of work and community. The Archival Collection of Ivan Henry Scheier: New Mexico.

Terosky, A. L. (2005). Taking teaching seriously: a study of university professors and their undergraduate teaching. New Yolk: Teachers College, Columbia University.

Terosky, A. L., O'Meara, K. \& Campbell C. M. (2014). Enabling possibility: Women associate professors' sense of agency in career advancement. Journal of Diversity in Higher Education 7 (1), 58-76.

Tight, M. (2002). What does it mean to be a professor? Higher Education Review 34 (2), 15-32.

Turiman, S., Hamzat S. R., Wan Mahzom, A. S., Mohd Rezal, H., Azizan, B., Ismail, A., Wan Ibrahim, W. et al. (2011). Determinants of student volunteering in Malaysian Public Universities. Paper presented at the International Conference on Youth Development, Palm Garden, Putrajaya. November 1-3.

Wilson, J. (2012). Volunteerism Research: A Review Essay. Nonprofit and Voluntary Sector Quarterly 41 (2), 176-212.

Wuthnow, R. (1999). Mobilizing civic engagement: The changing impact of religious involvement. In Skocpol, T. \& Fiorina, M., Civic engagement in American democracy, Washington, DC: Brookings Institution. 